\title{
GARCÍA MÁRQUEZ Y BARRANQUILLA
}

Julio Mario Llinás Ardila MD*

Durante el homenaje reciente que se hizo a nuestro Nobel, el Presidente de la República en su discurso no mencionó para nada las vivencias que Gabito tuvo en Barranquilla, ciudad en donde cursó algunos años de bachillerato en el colegio San José, de los Jesuitas, que muy probablemente dejaron su impronta en la juvenil mente. Pero lo que sí es imperdonable es que se olvidara de sus andanzas con lo que se ha llamado el Grupo Barranquilla formado junto con Álvaro Cepeda, Alfonso Fuenmayor, Germán Vargas y Alejandro Obregón, bajo la égida de José Félix Fuenmayor y Ramón Vinyes; de aquél, al decir de Bosch, el célebre escritor dominicano, García Márquez adquirió un estilo y por recomendaciones del sabio catalán, aprendieron a leer autores de vanguardia.

Como Fuenmayor Alfonso lo consigna en sus crónicas del grupo, en esas tertulias y parrandas aprendieron y conocieron las nuevas tendencias literarias que finalmente irían a producir ese estilo que ha dado en llamarse la realidad mágica que en forma ágil, amena, poética y desprendida, mezcla de crónica y relato, basado en una realidad que a veces es más virtual o fantástica que la misma ficción y que confunde a los que no nos conocen, son parte fundamental de la obra literaria de nuestro escritor y de los demás del grupo. También esas exuberancias se pueden ver en las pinturas de Obregón o de "Figurita", ambos a su manera.

El Grupo Barranquilla no fue un fantasma que se pueda desconocer aunque sus mismos integrantes, en forma por demás humilde, lo mencionen en voz baja y se pregunten si el grupo realmente existió. Todos los factores que han hecho que Barranquilla

Ginecólogo egresado del Hospital de San José, oriundo y residente de Barranquilla.

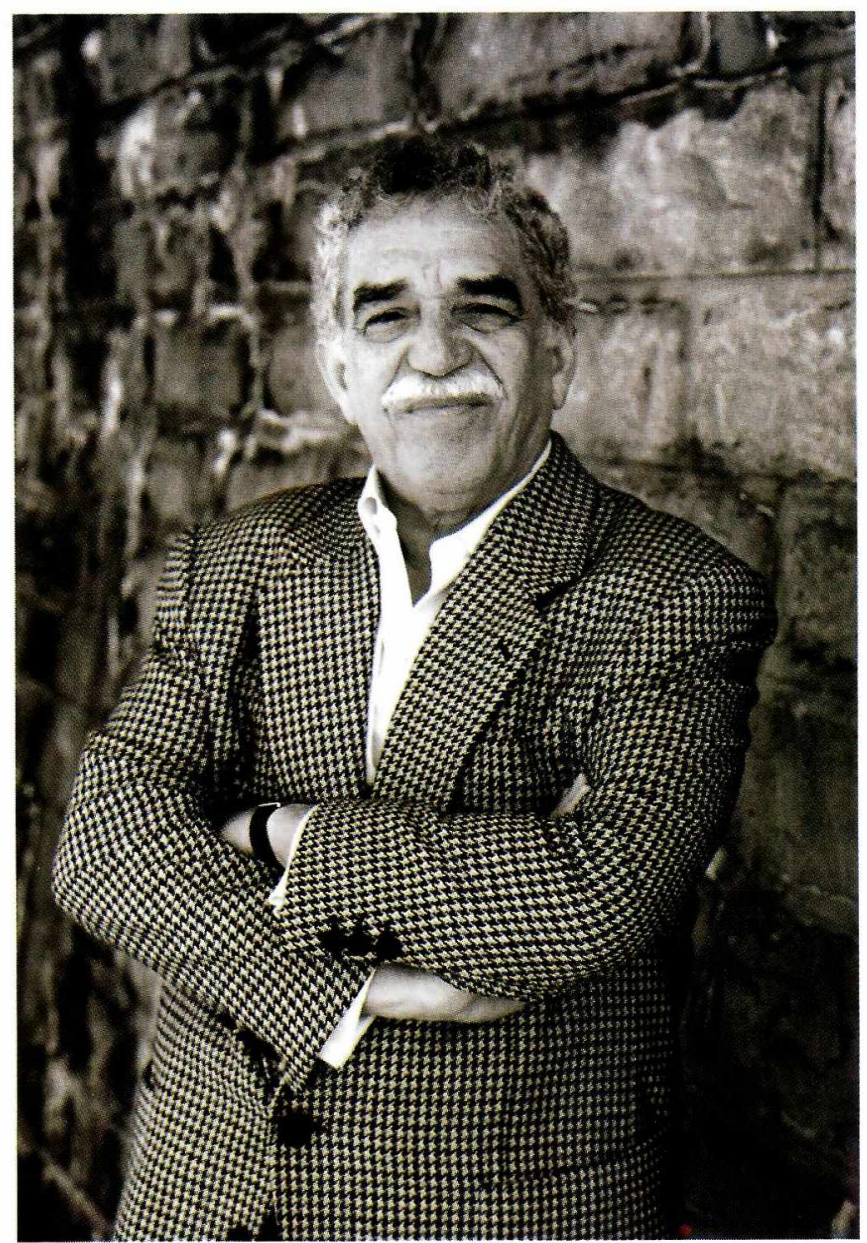

Fotografia: Daniel Mordzinski

sea Curramba y que sus gentes y su idiosincrasia hayan marcado y producido un fenónemo cultural, aunque ahora quieran desconocerlo, forman parte de la gloria de nuestro máximo escritor que ya es inmortal y pertenece a todo el país.

En Cartagena, Ramiro De la Espriella dice que Gabo aprendió el periodismo en El Universal, en Zipaquirá dicen que ahí aprendió a escribir, Aracataca se pavonea por ser su cuna y aquí en Barranquilla, además de lo dicho, Gabito conoció el amor y se unió a la mujer que lo ha acompañado por toda la vida. 